\title{
The Degree of Practicing Democracy in the EFL Classroom According to Perceptions of Instructors
}

\author{
Mohammad Akram Al-Zubi ${ }^{1}$ \\ ${ }^{1}$ English Department, Al-Balqa Applied University, Jordan \\ Correspondence: Mohammad Akram Al-Zubi, English Department, Al-Balqa Applied University, Jordan. Tel: \\ 96-277-565-3009. E-mail: dralzubi1978@bau.edu.jo; zubi1978@yahoo.com
}

Received: July 27, 2017 Accepted: December 12, 2017 Online Published: December 15, 2017

doi: 10.5539/elt.v11n1p136 URL: http://doi.org/10.5539/elt.v11n1p136

\begin{abstract}
One of the aims at Albalqa Applied University is to prepare the student to contribute positively in society so the main important goal of the comprehensive reform of the education system in Jordan is to contribute to the democratic development of the country. The study has been investigated to find out if the English instructors adopt the democracy techniques in their classes. This paper presents a classroom management model to be used in teaching English by having English teachers use the democratic process to create their English learning environments. The researcher prepared a "Democracy Scale" about the extent of applying democratization in EFL environment at universities as data collection tool. The sample was randomly chosen from Al-Balqa' Applied University. The study suggested several implications like using technology inside EFL environment and conducting a similar study to know students perspectives about practicing democracy in the EFL environment.
\end{abstract}

Keywords: democratization, EFL environment, democratization of education, students

\section{Introduction}

It is impossible to separate the society and the educational and democratic system. There is a strong relation between society and democracy from one side and democracy and education from another side. John Dewey and Piaget claimed that democracy and education affect each other. Dewey suggested that democracy should be taught in democratic institutions through instructors adoption of student-centered classes. Piaget focused on building experiences by students themselves. In his theory "constructivism", he concentrated on how students learn and on their needs to develop their skills (Mosher, Kenny, \& Garrod, 1994).

Karl Marx linked education to community to create "full human beings" (Ochoa \& Lassalle, 2008). Freire also refused the concept of "banking"; claiming that the students should be active not passive (Sartor, 2004). Most of the studies approved that if the instructors and teachers focus on the students' needs and interests, the students' achievement will be improved for example; (Alzu'bi, 2014) emphasized on using different methods like extensive reading program to improve language proficiency because such methods focus on students' attitudes and interests.

In 1999, King Abdullah recommended an economic democratic and educational development in Jordan. He has believed in the need to make the citizens have access to education and efforts have been made to build democratic nation. Thus, he encouraged practicing democracy in education by giving students the chance to be decision makers, to express ideas, and to participate in both classroom and real life.

Because of the advantages of the educational democracy, the researcher conducts the present study to discover the extent of applying democracy in teaching English as foreign language (TEFL) environment in Jordan from instructors' perspectives in order to develop the educational system in our country.

\subsection{The Objective and Question of the Study}

This study aims at revealing if English instructors' behaviors are democratic in the classroom by answering the following main question:

What is the extent of practicing democracy in the EFL environment according to English instructors' perspectives? 


\subsection{Significance of the Study}

This study is very important because it sheds light on democracy and its influence on the Jordanian society to recognize its effect on the educational system.

\subsection{Definition of Terms}

1) Democracy implies a system where an individual has the right to take part in decision-making or having equal right to benefit from a common good of a nation or society.

2) Democratization is a situation in which an individual is free to receive or enjoy certain things that belong to the society.

3) Democratization of education implies freedom of having equal access to education, since it is one of the fundamental human rights of every citizen.

\subsection{Related Studies}

KUŞ and ÇETIN (2014) conducted a study aimed at identifying the effect of some factors on the perceptions of democracy of primary school students. Also, the researchers compared their results with those obtained from other countries. The researchers used a scale to collect data about students' perceptions. The result of the study indicates two main results: First, sex, grade, education, and income play significant role in students' perceptions. Second, the perceptions of democracy scores for students in Turkey were low but they are high when they compared with the scores of students from other countries.

Kıroğlu (2013) conducted a study that aimed at revealing the extent to which social studies teachers' behaviors are democratic in the classroom. The researcher developed two scales (teacher form and student form) to assess the democratic behaviors of social studies teachers in primary school classrooms. The sample of the study consists of (194) teachers and (1712) students. Although the result of the study indicates that teachers' democratic behaviors are considered, they are not shared by their students.

Madumere and Olisaemeka (2011). Carried out a study that focused on democratization of education as a prerequisite for social, economic and cultural progress in a multi-cultural society, such as Nigeria. It tried to discuss the concepts of democratization, education, socialization, economy and culture. The paper also explained the role of education in various aspects of life and how it has enabled Nigeria as a multi-cultural society live in harmony as a strong united nation. The results revealed that efforts were made to relate democratization of education to socialization, culture and economy as a pre-condition for social, economic and cultural growth and development of Nigeria. Some factors like inadequate fund, economic recession and inadequate facilities were also identified as forces that hindered effective implementation of education as a major instrument for economic, social and cultural progress of Nigeria.

ŞEKER and TOPSAKAL (2011) investigated a study that aimed at examining the level of ability to adopt and apply organizational democracy by teachers and administrators in primary schools. The sample of the study consists of 486 teachers and 71 administrators who work at the public primary schools which are randomly chosen by the researchers. In this study, Şeker was prepared the instrument of the study which is "Organizational Democracy Scale". After analyzing the data, the study revealed that managers and teachers in primary schools have adopted organizational democracy but have reasonable view about practicability of organizational democracy.

Educational attainment and income affect on support for democracy. A study that conducted by (Shafiq 2009) showed that secondary education and higher education encourage support for democracy in Jordan, Lebanon and Pakistan. Moreover, poor people are more supportive of democracy in Lebanon and Turkey. Finally, there is no statistical relationship between belonging to the richest groups and supporting democracy.

Most of the previous studies were applied on school level but the present study conducted on university level in particular in EFL environment. Also, the sample in this study was selected from the instructors who are teaching English in the English Departments at Albalqa Applied University colleges. Finally, the study includes a developed scale by the researcher to discover the degree of practicing democratization in the EFL environment so the scale is different from the previous scales because it is specialized in teaching EFL.

\section{Research Methodology}

\subsection{The Sample of the Study}

The focus was on the instructors at English Departments in Albalqa' Applied University. The sample of 30 English instructors was selected from Ajloun University College and Irbid College, all of them are full-time; 10 
are female and 20 are male, with different specializations (literature, linguistics, methods of TEFL, and translation). It is also important to note that they are different ages and had more than 6 years of experience.

\subsection{The Instrument of the Study}

The democratic behaviors of the teachers in the English department were assessed by teacher scale developed by the researcher. It was administered in January 2016. The instructors' survey instrument includes 30 statements focused on how participants experienced democracy in teaching and learning process (See Table 2).

\subsection{Statistical analysis}

The means and standard deviation were used to compare the results.

\section{The Results and Its Discussion}

\subsection{The Result of the Main Question}

To answer the main question of the study, means scores and standard deviations of instructors' point views o practicing democracy in EFL environment were computed as shown in Table 2. Also, the following measurement was adopted to clarify the level of the statement as in Table 1 。

Table 1. Scale of statement levels depending on the means scores

\begin{tabular}{lll}
\hline Level-1 & Level-2 & Level-3 \\
\hline Strong & Medium & Weak \\
Above .80 & $.51-.79$ & Beneath .50 \\
\hline
\end{tabular}

Table 2. Means Scores and Standard Deviations of the Participants Responses on practicing democracy in EFL environment

\begin{tabular}{|c|c|c|c|c|}
\hline No. & Statement & Mean & $\begin{array}{l}\text { Std. } \\
\text { Deviation }\end{array}$ & Degree \\
\hline 1 & I involve students in making decisions inside the English class. & .57 & .504 & Medium \\
\hline 2 & I focus on community life and cultural practices. & .77 & .430 & Medium \\
\hline 3 & I am positive towards students who were cooperative. & .83 & .379 & Strong \\
\hline 4 & I always ask my students "Is this right? & .47 & .507 & Weak \\
\hline 5 & I take into account the interests of children. & .80 & .407 & Strong \\
\hline 6 & $\begin{array}{l}\text { I emphasis on teaching knowledge of the concepts of democracy like } \\
\text { "democratic government, and democratic society" }\end{array}$ & .47 & .507 & Weak \\
\hline 7 & $\begin{array}{l}\text { I teach knowledge of the college of the democratic government and civil } \\
\text { society in which the students live. }\end{array}$ & .30 & .466 & Weak \\
\hline 8 & I teach skills of democracy throughout the curriculum of the university. & .70 & .466 & Medium \\
\hline 9 & I involve students in extracurricular activities. & .63 & .490 & Medium \\
\hline 10 & $\begin{array}{l}\text { I tell my students that the future success of their government and civil } \\
\text { society depends on them as citizens. }\end{array}$ & .83 & .379 & Strong \\
\hline 11 & I respect my students & .50 & .509 & Weak \\
\hline 12 & I give my students freedom to select their choices. & .83 & .379 & Strong \\
\hline 13 & I am a facilitator not a transmitter of knowledge. & .80 & .407 & Strong \\
\hline 14 & I adopt student-cantered learning. & .80 & .407 & Strong \\
\hline 15 & Teachers should use appropriate teaching methods. & .80 & .407 & Strong \\
\hline 16 & $\begin{array}{l}\text { I listen to my students' explanations for misbehavior before making } \\
\text { decisions. }\end{array}$ & .73 & .450 & Medium \\
\hline 17 & I have a feeling of belonging. & .70 & .466 & Medium \\
\hline
\end{tabular}




\begin{tabular}{lllll}
\hline 18 & I use technology and multimedia at presenting my classes & .17 & .379 & Weak \\
19 & I Get students involved in planning lessons & .70 & .466 & Medium \\
20 & I Get students involved in teaching lessons & .43 & .504 & Weak \\
21 & I Get students involved in evaluating lessons & .20 & .407 & Weak \\
22 & I ask my students to participate without raising hands & .23 & .430 & Weak \\
23 & I take my students outside the classroom. & .63 & .490 & Medium \\
24 & I have a sense of humor! & .27 & .450 & Weak \\
25 & I let students determine what their homework is & .33 & .479 & Weak \\
26 & I ask my students to show their homework to others. & .67 & .479 & Medium \\
27 & I make tests when I am sure that my students prepare well & .23 & .430 & Weak \\
28 & I use voting on important issues for the school & .43 & .504 & Weak \\
29 & I give my students the chance to be researchers to learn. & .37 & .490 & Weak \\
30 & I always invite parents into university to participate in different activities & .70 & .466 & Medium \\
Total & .56 & .196 & Medium \\
\hline
\end{tabular}

Table notes: $\mathrm{SD}=$ Standard Deviation.

As can be seen from Table 2, the total's percentage of the mean score is $(56 \%)$ which means that the extent of practicing democracy in the EFL isn't strong enough. The instructors rated the following statements: "I am positive towards students who were cooperative.", "I tell my students that the future success of their government and civil society depends on them as citizens." and "I give my students freedom to select their choices." the highest. Then they gave low ratings to the following statements: "I use technology and multimedia at presenting my classes" and "I get students involved in evaluating lessons. It means that the instructors didn't use technological devices in teaching their students. Also, they didn't involve their students in the process of evaluation.

For the researcher knowledge, the total percentage of applying democracy is moderate because of several reasons; firstly, students weren't given opportunities to be the center of learning and teaching by applying democracy in the educational situations. Also, our society doesn't practice all of democratic values inside the real society so it leads to not increasing democracy in the EFL environment so if the political and social democracy is absent, it reflects on the democracy of educational system. Finally, there is a relation between teacher's democratic beliefs and effective teaching (Shechtman, 2002).

\subsection{The Recommendations}

The researcher recommended to

1) Raise awareness about the need and the importance to practice democracy and its influence on students' learning by decision makers, in particular, a need to educate teachers about the importance of the democratic value of freedom and how it can be practiced in the classroom.

2) Apply democracy in all stages like the elementary classroom.

3) Conduct similar studies to know the students' point view about the extent of practicing the democracy in the EFL environment.

4) Increase the role of the students' involvement and participation in the process of learning and teaching by instructors and teachers.

5) Use more technological devices and e-learning in teaching and learning process.

6) Conduct similar studies on society because if we want to apply democracy in our classes effectively, democracy should be adopted and in our real society.

\subsection{Conclusion}

This study has discussed the degree of practicing democracy in the EFL classroom according to perceptions of instructors. It concluded that the instructors didn't apply the principles of democracy enough 


\section{Acknowledgement}

I would like to express my special thanks to my university (Al-Balqa Applied University) which gave me the opportunity to do this project. Iam realy thankful because the whole of my project is financed by Al-Balqa Applied University.

\section{References}

Alzu'bi (2014). The Effects of an Extensive Reading Program on Improving English as Foreign Language Proficiency in University Level Education. English Language Teaching, 7(1), 28-35. http://doi.org/10.5539/elt.v7n1p28

Kiroglu, K. (2013). Is My Social Studies Teacher Democratic? Egitim Arastirmalari -Eurasian Journal of Educational Research, 50, 127-142.

Kuş, Z., \& Çetin, T. (2014). Perceptions of Democracy of Primary School Students. Educational Sciences: Theory \& Practice, 14(2), 786-790.

Madumere, S. C., \& Olisaemeka, B. U. (2011). Democratization of Education as Prerequisite for Social Economic and Cultural Progress in a Multi-cultural Society. US-China Education Review, 7, 982-987.

Mosher, R., Kenney, Jr., R., \& Garrod, A. (1994). Preparing for citizenship - teaching youth to live democratically. Westport, CT: Praeger.

Ochoa, E., \& Lassalle, Y. (2008). Editors' Introduction. Radical History Review. https://doi.org/10.1215/01636545-2008-001

Sartor, L., \& Brown, M. Y. (2004). Consensus in the classroom: fostering a lively learning community. Mt. Shasta, CA: Psycho synthesis Press with Consensus Classroom, Inc.

Şeker, G., \& Topsakal, C. (2011). The Level of Ability to Adopt and Apply Organizational Democracy to Primary Schools According to Perceptions of Teachers and Administrators. Theory \& Practice, 11(3), 1222-1227.

Shafiq, M. N. (2009). Do Education and Income Affect Support for Democracy in Muslim Countries? Published article, Educational Leadership and Policy Analysis, Indiana University.

Shechtman, Z. (2002). Validation of the democratic teacher belief scale (DTBS). Assessment in Education, 9(3), 363-377. https://doi.org/10.1080/0969594022000027672

\section{Copyrights}

Copyright for this article is retained by the author(s), with first publication rights granted to the journal.

This is an open-access article distributed under the terms and conditions of the Creative Commons Attribution license (http://creativecommons.org/licenses/by/4.0/). 